\title{
Reading Sovereignties in the Shadow of Settler Colonialism: Chinese employment of Aboriginal labour in the Northern Territory of Australia
}

\author{
Ben Silverstein ${ }^{1}$
}

\section{Introduction}

Australia's tropical north has long been positioned by both governments and historians as a space marginal to the nation, one far from the archetypal situations of white Australia or settler colonialism that can be found in the southeast. At the moment of Australian Federation in 1901, which formally signified the closure of the Australian frontier, most of those living in the Northern Territory were Aboriginal, and a small non-Indigenous population of mostly Chinese people relied on Aboriginal labour in order to fabricate viable lives in a relatively new settler colony. How might a history of settler colonialism take shape if we begin from such a place? This article approaches that inquiry by asking how we might take these apparently marginal people in an allegedly marginal space not as marginal at all, but rather as the central actors in a story taking place on and through Aboriginal country. ${ }^{2}$ It operationalises a settler colonial analytic that centres Indigenous situations to tell stories of settlers, migrants, and the conditions of Indigeneity. And it does so to illuminate the centrality of Indigenous sovereignties as actors continually shaping the process of making a settler colonial nation.

We might begin with a contest over rights that emerged as the white settler state imposed legal disabilities on Chinese people's capacity to work, employ, and survive in Darwin, the tropical capital of the Northern Territory. As the Territory was being prepared for transfer from the state of South Australia to the Commonwealth government in 1911, legislation was drafted and amended to ban 'Asiatic aliens' from working on any new minefield or as wharf labourers, from acquiring fishing licences, or from performing any work on a government tender. The new Aboriginals Act declared the Chinatowns in Darwin and Pine Creek to be 'prohibited areas', banning unregulated Aboriginal access to these spaces, and removed from persons of 'Asiatic race' the right to employ Aboriginal people. The Chinese community responded to these denials of rights to work and rights to employ through meetings and letters-with both Chinese and European signatories-denouncing the injustice. And their campaign culminated in a meeting between a deputation of Chinese residents of Darwin and Josiah Thomas, the new Commonwealth Minister for External Affairs responsible for the government of Australia's Territories, who in May 1912 toured the Northern Territory to mark the commencement of his political authority. ${ }^{3}$ At that meeting, twelve deputies mainly protested the policies that targeted 
their relationships with Aboriginal people, relating stories of Chinese people who would suffer 'hardship' as a result and extracting from the Minister an assurance that if he could meet their wishes 'without violating the "White Australia" policy' he would do so. But this proved impossible, and ultimately the Government proceeded to impose these restrictions without amendment. ${ }^{4}$

How can we read this argument between white administrators and Chinese settlers? One possibility is to study the way it reflects and reiterates a series of racialised distinctions between non-Indigenous peoples, for the ways it articulates whiteness at the heart of a settler colonial project and casts Chinese people as marginal, perhaps not as settlers at all. Such an account might place it in a broader north Australian context to demonstrate that Chinese affiliations with both Aboriginal people and white settlers remained emergent and unsettled; that relationships were both malleable and contingent. This kind of study has exercised a good deal of scholarship engaging with and in settler colonial critique in recent years, evidencing the problems and possibilities of Indigenous relationships with migrants or settlers, the performative appropriation of settler sovereignty over Indigenous country, and the white settler rejection of other peoples through techniques of racialisation and expulsion. Such studies could lead to analyses of binary oppositions and triangular structural models, of whiteness and settlers of colour, of overdetermined implication or voluntarism at the basis of settler identity.

This kind of work has characterised a major strain in scholarship published under the rubric of settler colonial studies. But in this article I want instead to take up J. Kēhaulani Kauanui's recent call for scholars to tend to the question of Indigeneity alongside, and as a necessary counterpoint to, that of settler colonialism. ${ }^{5}$ What happens when we centre the Larrakia people of Darwin, asking how their historical situation - their sovereignty - is debased and deferred by arguments over other peoples' rights which take place through their predicament? I suggest that an account that takes settler colonialism seriously in its relation to Indigenous peoplewhat Patrick Wolfe described as a 'negative articulation'—can provide the grounds for such a study. For Wolfe, this repressive relationship is not incidental; it is the central structuring element of a settler colonial formation. The history of settler colonialism, in other words, is structured by the expropriation of Indigenous land and a corresponding 'logic of elimination' alongside the dynamic responses of Indigenous people which necessitate constant settler revisions and transformations, constituting that logic as adaptive and contingent. This is a theory of the settler colonial condition that recognises 'the Indigenous presence as an absent center that structures settler discourse' and practice in all contexts. ${ }^{6}$ 
We might navigate this turn from the study of settlers to a study that centres Indigeneity through a sovereign heuristic. Sovereignty is often at the heart of settler colonial analyses. In Lorenzo Veracini's influential theorisation of a triangular structural model of the settler colonial situation, sovereignty does the work of distinguishing between populations. In his theory, settlers possess sovereignty, carrying it with them from metropole to colony. Migrants do not, instead arriving in a settler colony to find themselves subject to the sovereignty of settlers. And Indigenous peoples' sovereignty is negated, refused recognition and rendered prone to elimination.7 Sovereignty emerges here as a scholarly technique of differentiation between peoples, a method of discerning the distinctions between those living on-perhaps occupying, appropriating, or possessing—but not of, Indigenous lands. And in this model sovereignty is itself understood as a possession, one available to specific subjects, able to be carried, abandoned, or negated, and either dominating or being dominated. But it need not be so described. In this article I instead understand sovereignty as a practice or process, as the effect of sovereign acts. This approach takes sovereignty as something that is done, rather than something possessed, and consequently leads us to ask different questions: not who carries sovereignty but how do different actors produce it; not how are sovereign capacities recognised, but how do people enact themselves as sovereign. Consequently, in this article I approach Aboriginal sovereignties not by providing a declarative and encompassing definition but by tracing its manifestations, practices, and performances. Following Crystal McKinnon's argument that what has often been read as Indigenous resistance to colonialism is better 'appreciated as a continuous but dynamic expression of sovereignty that has never been ceded or diminished', I trace the ways that Larrakia people enacted their sovereignty in the contested context of Darwin in the early twentieth century. ${ }^{8}$

This article first engages with the extensive scholarly literature that seeks to describe the structure of settler colonialism to delineate settler specificities and differentiations, and suggests that reading settler colonialism through Indigenous sovereignties may instead direct our attention to the conditions of Indigeneity. The article thus engages with one of the key debates that has animated settler colonial studies in recent years-who are the settlers?-and instead turns to centre Indigeneity and ask how, in the context of the Northern Territory in 1910-12, Aboriginality fundamentally structured a settler colonial situation. Considering settler colonialism in this way enables a critique which Dean Saranillio argues takes power as both targeting 'historically oppressed communities' at the same time as it 'operates through their practices, ambitions, narratives, and silences'. It allows us to explore the ways 'power operates relationally' such that we are able to think northern Chinese communities not as 'either oppressed or oppressive' but as located firmly within a settler colonial dispensation, one whose 
operation is bolstered by their presence even as it drastically constrained their participation in part through the threat, or practice, of exclusion. ${ }^{9}$ The article then returns its focus to the argument about Chinese rights and Aboriginal labour to explore the question and practice of sovereignties in the Northern Territory. It examines Indigenous sovereignty-making through relating with country, moving over it, telling its stories, and practicing its ceremonies. And it explores settler sovereignty as a counter-claim, as the dual practice of denying Indigenous sovereignties by seeking to prevent the labour of sovereignty-making and fabricating a countersovereignty through a biopolitics of the settler population. ${ }^{10}$ Examining settler sovereignty as responsive and productive in these ways, this article suggests, can locate Indigeneity and settler colonialism in the same lens.

\section{On triangles, triads, and binarisms}

As has often been noted, the recent efflorescence of scholarship examining settler colonialism draws much from Wolfe's (neo-)structural elaboration of its specificity as a response to the 'oddly monolithic' notion of colonialism that circulated in postcolonial studies. ${ }^{11}$ In his work on Australian history, building on the work of black and Indigenous scholars who had earlier emphasised colonial continuities, Wolfe discerned a form of colonialism 'premised on displacing indigenes from (or replacing them on) the land'; a form that, in the absence of decolonisation, continues to prevail albeit in new iterations. In response and critique, and in an effort to resist reproducing settler colonial discourse, he insisted on recognising and operationalising a binary approach to settler colonialism. Writing in the context of several decades of assimilationist policy that was designed to absorb Aboriginal people into the Australian nation, Wolfe's approach instead reasserted a fundamental distinction between settlers and natives that had been, initially, an effect of the frontier. Describing the persistence of this distinction into the present was a scholarly move intended both to refuse the assimilationist ideology whereby Aboriginal people with white ancestry were constructed as themselves becoming white, and to undo the 'strategic pluralism' which worked to 'blur the polarity of the relation of invasion' by reducing 'the primary Indigenous/settler divide to the status of one among many ethnic divisions within settler society..12

This latter part of Wolfe's argument, on the obscuring function of multicultural discourse, was perhaps under-theorised in its early articulations and has since been the subject of critique and revision by other scholars. In her critical race scholarship, Aileen Moreton-Robinson has provided a compelling alternative account that centres whiteness as a possessive subjectivity and thus implicitly appended the modifier 'white' to any proper use of the term 'settler'. For her, 
since at least the end of the 18th century, whiteness has been constituted both through and on the basis of increasing control of Indigenous country which was, in turn, articulated as possessable, as an object onto which the patriarchal white self could impose his will. Whiteness and possession (of Indigenous lands), for Moreton-Robinson, are ontologically entwined. ${ }^{13}$ The critic today consequently can - in fact they must—differentiate between possessive white settlers and others. And this speaks also to the conditions of Indigenous lives. For MoretonRobinson, whiteness transforms Indigeneity into its possession; her work powerfully critiques both the constitution of whiteness through such appropriation and the experience of living Indigeneity under such appropriative and extractive conditions. ${ }^{14}$

A number of scholars of settler colonialism have also developed models that differentiate between settlers and other classes or communities of non-Indigenous peoples in settler colonial situations, often on the basis of sovereign possession rather than racialisation. Some have developed triangular structural models, as in the case of Veracini, for whom that structure is an effect of the 'irruption into a specific locale of a sovereign collective of settlers' and the 'negatively defined alterities ... brought into existence' as Indigenous or exogenous as an effect of those settlers' sovereignty. ${ }^{15}$ Other scholars, particularly (though not exclusively) those working in Indigenous studies or in the North American field of critical ethnic studies, have sought to disaggregate the category of 'settlers' by differentiating between those who purposely come to stay in and possess Indigenous spaces and those whose presence in the settler colonies is both coerced (or entirely forced) and precarious. Jodi Byrd has influentially described the relationships between Indigenous peoples, settlers, and arrivants in the Americas, borrowing the latter term from Kamau Brathwaite to signify those people who were 'forced into the Americas through the violence of European and Anglo-American colonialism and imperialism around the globe'. This differentiation, which emerges from circumstances of arrival and degree of inclusion into the rights of settlers thereafter, is ameliorated by the way 'settler colonialisms ... coerce arrivants into complicity' as 'imperialism has forced settlers and arrivants to cathect the space of the native as their home'. The overlapping relationships characteristic of her triad reveal 'colonialism as a cacophony of contradictorily hegemonic and horizontal struggles'. ${ }^{16}$

These varied struggles have related but distinct elements at different scales. Eve Tuck and K. Wayne Yang describe the function of a world system that brings 'dispossessed people ... onto seized Indigenous land through other colonial projects' which draw settler colonialisms into broader processes that constitute an imperialist world through uneasy and often abrasive complementarities. Historical processes of racialised exploitation and Native elimination have aided and abetted each other in turn. ${ }^{17}$ But, despite the importance of keeping this imperial 
scale in view, there are nonetheless good reasons to focus our account primarily on a situated perspective. Such a standpoint centres Indigenous lands and the competition for them that emerges as a result of a settler colonialism that is both local and global. For Tuck and Yang, 'colonial subjects who are displaced by external colonialism, as well as racialized and minoritized by internal colonialism, still occupy and settle stolen Indigenous land. Settlers are diverse, not just of white European descent, and include people of color, even from other colonial contexts.' This is a view that is both situated and transcolonial, centring Indigenous lands but accounting for broader, and interlinked, contexts. ${ }^{18}$

Approaches that turn to centre these contexts outside Indigenous homes can be useful in elaborating the lives and experiences of settlers, of providing nuance to discussions of 'the settler' or 'the settler self' which might otherwise proceed as though one could speak of a unitary category. Elaborating this heterogeneity, though, is less useful when concerned with describing subjects through their relation to whiteness rather than Indigeneity, or in performing the analytic task of locating non-Indigenous people of colour apart from a settler collective, as not settlers. ${ }^{19}$ Settler colonialism works through producing subjects as settlers, not a matter of voluntarism or will, but as a matter of structural implication. Settlers are not born; they are made. ${ }^{20}$ To be a produced as a settler is to be produced by the historical conditions of settler colonialism at the centre of which are processes of Indigenous dispossession. ${ }^{21}$ To pose questions of structural complicity rather than identity is not, I believe, to deny the importance of diverse and often coerced migratory histories, but to note the imperial complementarities (and incoherencies) that can both displace peoples and render them complicit with displacement elsewhere. As a consequence, we/they are made settlers differently. The processes that activate subjects as settlers are constituted through and on the basis of difference, enacting intersecting processes of racialisation, gendering, and class to produce a settler collective whose integrity is always contingent and suspect. The representative 'settler' is an elusive figure.22

But amidst this diversity we can nonetheless discern a fundamental distinction between Indigenous and non-Indigenous peoples, a distinction that lies at the heart of the settler colonial situation. Insisting on this basic difference is crucial to retaining the priority of Indigeneity. NonIndigenous heterogeneity glossed as multiculturalism ought not to reduce Indigeneity to just one more culture in a proverbial national mosaic. ${ }^{23}$ Fundamentally, as Candace Fujikane has argued, an analysis of settler colonialism should work to position Indigenous people at the center, foregrounding not settler groups' relationships with each other or with ... [an external or overseeing] state, but with the indigenous peoples whose ancestral lands settlers occupy'.24 And as Moreton-Robinson tells us, an 'ontological relation to land constitutes a subject position that 
we [Indigenous peoples] do not share, and which cannot be shared, with the post-colonial subject whose sense of belonging in this place is tied to migrancy'. ${ }^{25}$ This relation is an artefact of history rather than will; a history which compels us, in discussing difference, to account for the prior dispossession of Indigenous peoples that creates the ground on which racialised non-Indigenous differentiations can be both articulated and operationalised. ${ }^{26}$ Settler colonial situations are characterised by an underlying binarism in the analysis of which 'what matters', as Stuart Hall has argued in relation to a different colonial context, 'is not simply the plurality of their internal structures, but the articulated relation between their differences'. ${ }^{27}$ The 'settlers' of settler colonialism are those who comprise a society that works to displace Indigenous people and replace them on the land. In returning our focus to northern Australia, we will find that using a study of sovereignty-making to foreground the plural articulations of race that overdetermine relationships between peoples illuminates the ways Chinese people-or perhaps settlers of colour more generally—are not 'intrinsically allied'28 with either settler or Native peoples, but instead practice affiliations through processes animated by desire, economy, or simply the search for the necessary conditions of life.

\section{On sovereignties}

A claim of sovereignty is often understood to refer to an assertion of supreme authority over people and territory. But, as many scholars of colonialism and Indigeneity have made clear, sovereignties across empires or colonies are almost always multiple and contested. ${ }^{29}$ For Jean Dennison, for instance, entering into the politics of sovereignty does not mean engaging in a 'zero-sum contest for power'. Instead, she insists, it is to be entangled. In her account of Osage nation practice, sovereignties emerge as 'deeply interconnected', operating not as exclusive authority but as 'an ongoing process of engagement with other authorities'. But how can we map the precise shape of that entanglement?30 And how does it help us reckon with the ways sovereignty is both the stake and the site of contestation in settler colonial situations? In this section I examine the ways settler sovereignty emerges as what Manu Vimalassery describes as a 'reactive ... claim of counter-sovereignty'. ${ }^{31}$ So we might then trace processes of claim-making, of fabricating sovereignty through ongoing negotiation, or of practicing sovereignty amidst relations and responsibilities, nurturing spaces and constraining obstructions. ${ }^{32}$ And we can do so through returning to the specificity of Australian Aboriginal sovereignties.

In describing the character of Aboriginal homeliness, Moreton-Robinson writes of peoples who trace their belonging through historical communities who own, live on, are taught to know, and belong to tracts of 'country'. A relation to country, through which Aboriginal peoples articulate 
belonging, derives from the Dreaming, a term which encompasses the creation of land and life along with moral codes with rules for what can and cannot be done. For Moreton-Robinson, Aboriginal sovereignty is 'grounded within [these] complex relations derived from the intersubstantiation of ancestral beings, humans, and land'.33 Alexis Wright similarly articulates a 'sovereignty of the mind' as the basis for and an effect of communal sovereignty, writing of relationships between the self, other people, and country. She describes land characterised by force and duration that evokes both creation and the present, ancestral beings and Indigenous people today, and that communicates through stories told by country and by people. These practices of thinking about and telling stories, in forms appropriate for and derived from country, can represent and constitute that sovereignty of the mind. Such stories trace relationships between peoples, land, sea, and ancestral beings. They locate the human within a complex of forces and times to which they relate from a position of intimate interconnectedness rather than from authority. These relationships, and the laws that govern them, are constituted by storytelling. Sovereignty of the mind, this capacity to tell these stories, Wright argues, is essential to practicing sovereignty of the land. ${ }^{34}$

These are representations of sovereignty that resemble, but do not derive from, a conception of political authority. Rather they emphasise sovereignty as both the basis and the effect of relationships and responsibility, people and country, law and story. It is the practice of renewing and rearticulating these elements that, in turn, renews and rearticulates that sovereignty. And what emerges is not individual self-possession or possession of authority, but an imbrication in a wider complex that comprises humans, animals, lands, seas, rules, laws, stories, and language. Learning from this conception of sovereignty directs us to consider the ways it is practiced, the worlds to which it relates, and the ontologies that render it durable and meaningful.

\section{On dispossession, labour, and managing a sovereign population}

In returning to Darwin, to the episode with which this article began, we need therefore to attend to Larrakia country and its sovereignty, to Larrakia people's relationships with the land on which the town of Darwin sits. The argument between the Chinese community and the white administration was, most immediately, a contest over the right to employ Aboriginal workers in a small town that was also a regional capital in northern Australia. And in approaching this as a story of work one might be tempted to turn our attention to the ways Larrakia people had become both required and available as labourers, to trace a story of their dispossession as primitive accumulation. It might trace a process of dispossession of land as economic resource, 
and the concomitant availability of Larrakia people for wage labour. But we need also to go further, to discuss that dispossession as a strategy for severing Larrakia connections with country as a source of law, of relations and obligations, of responsibilities, and fundamentally of Larrakia peoplehood. ${ }^{35}$ This was not just a struggle for land, but more crucially a struggle about land, about its meaning and nature, its ontology, its relationality. When we centre our analysis on this struggle, the debate between Chinese and white settlers appears as a contest over forms of sovereign relations, a dispute relating to techniques of frustrating Aboriginal sovereignty and producing settler counter-claims.

Dispossession took many forms in early twentieth century Darwin, not least working through intensifying practices of containment, regulation, and surveillance which were designed to regularise Aboriginal labour. From 1913, Aboriginal workers in Darwin were confined to Kahlin Beach Compound, a space the Chief Protector, Baldwin Spencer, intended as a site both 'capable of easy supervision and situated far enough away from the town to make it possible to isolate the aboriginals when necessary, as, for example, at nighttime, and at the same time be near enough to allow of those in employment in Darwin to walk to and from their daily work'. ${ }^{36}$ Under this urban labour regime, then, Aboriginal people were not permitted to be lawfully in Darwin itself without specific authorisation from an accredited employer. But the dispossession of Larrakia people through their confinement here may have frustrated, though not destroyed, practices of relation to country. The regime imposed at Kahlin hints at continued Larrakia mobilities. Xavier Herbert, the writer and former Compound Superintendent, described Aboriginal people's illicit movements between town and bush in the 1930s, 'spend[ing] half their time in the traditional way and half their time working in here. Everybody endeavoured to do that to try to get walkabout. '37 Through these practices of mobility, glossed as 'walkabout' by Herbert, Larrakia maintained their practices of country, maintained their peoplehood. And while the white administration may have understood a move into domestic service as a move away from Aboriginal belonging, work for settlers in Darwin and Larrakia economic and ceremonial practices were not, in practice, mutually exclusive. Larrakia woman Pauline Baban remembered her grandmother, Ruby Ariyat Ababa using her position as a domestic worker at Government House in the 1920s to enable access to the Darwin township and to use that access to convey knowledge: 'She taught a lot of the Larrakia town mob, visited them all the time and went with them to places like Dinah Beach and Mindilgwa (Mindil Beach) and around Vesteys showing them how to get longbum and crab, you know, all different type of shellfish.' 38

These relations have also been reconfigured and reimagined in new circumstances. In the context of recent land claims, Larrakia people have described relating to land through 
ceremonial practices and stories which are 'owned' by specific people, constituting what some anthropologists have termed 'rights to knowledge and rights to transmit knowledge about it'. But these rights can also be conceived as responsibilities. Larrakia people might see their role less as the exclusive owner of a ceremony, for example, than as primarily a custodian of knowledge of a ceremony that is essential not just for the people who are responsible for it, but for country itself. ${ }^{39}$ Larrakia people have, over the past 150 years, persistently sought to fulfil responsibilities to country by ensuring the transmission of knowledge and practice, sometimes through relationships with people of other nations. Moving over country, practising ceremony, and telling stories constitute engagements that maintain both people and land. Country, and engagement with that country, is fundamental here not just as economic resource, but as a basis for Indigenous sovereignty. 40 And it is not just an inert basis: sovereignty was and is produced through productive interactions, through working on and with and alongside country. Relating to country through the work of ceremony produces the group as a self-determining people; it is a practice of sovereignty. Larrakia practice, in other words, offers us a way of speaking about sovereignty that is not determined by a settler sovereignty that was characterised, and continues to be characterised, by claims to authority based in racialised stratification or domination. Instead, these are sovereignties as practices of relationality and connection, of maintenance and care, which, through Larrakia labour, endure the forces of settler colonialism that seek to consume them.

A process of transforming Aboriginal people into workers for settlers, then, was articulated to produce a settler sovereignty in two ways. First, it would frustrate the kind of group-making and sovereignty making labour-mobility, storytelling, relationality — that characterised Larrakia peoplehood. It is no coincidence that Aboriginal people of Darwin and surrounds so often describe domestic servitude in white homes as slavery. For Gurindji woman Daisy Ruddick, who was confined in Kahlin in the 1920s, '[t]he intention of the government was to make them slaves for the whites, prepare them to work for white people in the Darwin Community. That's what happened.'41 Just as slavery is more than simply a work relationship, dispossession was not merely an economic process. It made some kinds of labour almost impossible and others essential. And work produces identities, collective and individual. Inducing or coercing Larrakia people to work for settlers was part of a settler colonial economy of labour that was intended to transform Aboriginal people from sovereign subjects to slaves, people who may continue to seek to fabricate spaces of self-determination but whose efforts would often be frustrated. 
And second, this process would articulate working Aboriginal people as an essential supplement to the settler population, rendering white settler life viable in the tropics and thus producing a white population the effect of which would be white settler sovereignty. Aboriginal labour had become indispensable in the northern colonial situation, both as domestic labour across the Northern Territory and pastoral labour in its rural areas. Many settlers, whether white or Chinese, believed that life in the tropical north could not be sustained without access to black labour in the form of domestic servants, manual labourers, stock workers, boatmen, and so on. ${ }^{42}$ A settler population, then, was dependent on access to Aboriginal workers: stripping Chinese settlers of this access was meant to drive them away. The debate over the right to employ Aboriginal people was, then, an argument over the composition of a settler population transacted through the question of Aboriginal work.

This population management was considered to be the source of a settler sovereignty that was, in the Northern Territory, constituted through and on the basis of a series of specific and differently racialised relationships between peoples. Homogeneity underpinned the constitution of white settler sovereignty. '[T]here is only one means by which we can hold the Territory, and that is by having there a settled population', declared the Minister for External Affairs Littleton Groom in 1909. His Labor opponent Lee Batchelor, who was to succeed Groom as Minister, agreed that the 'only genuine right to a country is that which population, effective occupation, and settlement give'. Population, in other words, would produce sovereignty. ${ }^{43}$ And by this they meant a white population, a secure, expanding, and homogeneous agglomeration of people. Only such a population could become sovereign. So the Commonwealth government crafted a specific northern population economy, articulated to consolidate national possession. Race was fundamental to consolidating that population-possession-sovereignty nexus. As the Prime Minister of Australia Alfred Deakin declared, the primary consideration in taking on the Territory was not commercial but was 'national, first, second, third, and last. ... The Territory must be peopled by a white race.' It was 'time,' argued Labor politician James Fenton, 'that there was a decrease in the coloured population'.44

When the Chinese deputation met with the Minister in 1912, their community was consequently under siege. Though Chinese settlers had thrived in the Northern Territory since the 1880s, they were being driven out by a combination of immigration restriction laws and other constraints imposed after Federation in 1901. 3784 Chinese people had resided in the Northern Territory in 1891, but only 1339, just 111 of whom were women, remained by the time the Commonwealth took over in 1911. That year was, the Commonwealth Annual Yearbook recorded, 'the first in which the population was dominated by the European race'. ${ }^{45}$ Now a 
minority of the total non-Indigenous population - which was counted at 3233 people-Chinese futures in the north were precarious. The bans the Chinese settlers contested were part of a set of measures whose effect was to police the population by securing racialised boundaries that denoted legitimate and illegitimate members: those favoured who could live in this place, and those scheduled for exclusion who could not. To make these boundaries effective the Commonwealth sought to make Chinese life in the Northern Territory unviable, mediating the endemic conditions under which they lived. The Chinese deputation to the Minister recognised this, setting out the consequences of the restrictions now imposed upon them. 'There are' now, they said, 'many Chinese in destitute circumstances with no prospect of improving their condition. All we ask is that we may be allowed the right to live, and unless we are, there is no alternative but starvation; because a great many Chinese have no money wherewith to take passage to China'.46 Declared disposable, departure or starvation were the twin options available to Chinese settlers. This was a biopolitics working towards a homogeneous settler population.

Against this, the Chinese community insisted that they formed a constitutive part of the settler population. They described people who had long been part of a local community, whose claim to the rights of a settler was based in decades of labour and investment. Some Chinese had 'been engaged' in work from which they were now prohibited 'for over 30 years' and the population of Darwin had become dependent on their industry. They referenced their 'allegiance' owed to Australia, often as 'natural born British subjects' born either in Australia or in Hong Kong, and argued that they were 'fit persons to be licensed to employ aboriginals', having done so 'for years and have always treated them well'. Perhaps most importantly, the Chinese position was articulated through a proclaimed commitment to settling in Darwin. One group of Chinese petitioners wrote that 'most of us have lived in Palmerston [renamed Darwin in 1911] for a great many years. At the time we came we were free to do so and to settle here. We expended our money in business here $\&$ have always been law abiding and paid our rates and taxes and in every other respect conformed to general \& local laws.' They made no complaint about the immigration restrictions imposed since 1901, but asked only 'that the Chinese who are left shall not by future legislation be adversely affected as against the rest of the community without any compensation or redress'. ${ }^{47}$ In this argument, in other words, they articulated themselves as settlers, as part of a heterogeneous settler population. But this celebrated heterogeneity collided with the white Australia to come that was presumed to provide a basis of settler sovereignty. To do away with Aboriginal sovereignty and to produce a settler countersovereignty meant, for white administrators, excluding Chinese settlers. 
In examining settler sovereignty as a counter-claim, we are reminded that far from the presumed absence of recognition of Indigenous sovereignties in Australia, in fact settlers have often practiced a form of recognition. ${ }^{48}$ Settler sovereignty, that is, is not so much problematised by the appearance of Indigenous sovereignty as it is exercised by it, iterated as a response to it. This is not to say that Indigenous sovereignty does not or could not destabilise settler sovereignty; it can and it does. But it is to re-think the relationship between sovereignties. Australian settler sovereignty does not deny recognition to Indigenous sovereignty so much as it denies having recognised it. Assertions of settler sovereignty appear in a register of disavowal or negation, always already premised on that recognition, responding to dangerous assertions by forming new means of enveloping them, never succeeding in resolving the contradiction but instead constituting itself as antagonistic. A binary remains.

I have argued here that a settler colonial framework represents one way to write a history in which Indigenous people are neither absent nor erased, in which they do not appear as merely obstruction or resource, but a history in which Indigeneity is a crucial pedestal on which the settler nation rests; in which Indigenous sovereignties are both an object through which settler sovereignty must transit and a continual practice interrupting the elusive completion of settlement. This article has situated a debate over Chinese rights as a debate about a dispossession that was primarily articulated to frustrate Indigenous sovereignty, but was also designed to regulate the composition of a specifically settler population in order to produce settler sovereignty. We can understand the debate, then, as an effect of a settler colonialism that should be read not as a single minded practice of elimination but rather as what Byrd has described as a 'cacophony' of contradictions and competitions, working both through and against a plethora of interrelated colonial differences. This conduces to a reading practice that intervenes to reinstate the priority of colonisation, that allows us to centre Indigenous situations even in arguments where Indigeneity is reduced to an apparently containable residue. Indigenous people's persistent practices of sovereignty reminds us that settler sovereignty is produced in response to, and by consuming, Indigeneity; that settler colonialism comprises practices of recognition and counter-claim. Reading settler colonialism through its recognition, and through the Indigeneity that exceeds its gaze, reminds us of the settler dependence that means we all, always, live in relation to Indigenous sovereignties. Our task is to relate differently, to cultivate dispositions and work towards relationships that neither deny the structural implications of settler colonialism nor seek to reproduce its antagonistic character. 
1 Thanks to Jane Carey, Lorenzo Veracini, Maria Elena Indelicato, and Sarah Walsh, who read earlier versions of this article and whose comments helped frame it. Thanks also to the two anonymous referees. This work was supported by the Australian Research Council (FL170100121).

2 On 'marginality', see Gabriella Haynes, 'Shifting Foundations: A Short History of Subversive Spaces on the Pioneer River,' Australian Historical Studies, 48(4), 2017, pp. 536-53.

3 J J Symes to W Baldwin Spencer, 14 February 1912; Petition to the Honorable Josiah Thomas, Minister of State for External Affairs, n.d., National Archives of Australia: A1, 1912/6611; Notes of Deputation from Chinese Residents of Darwin Which Waited Upon the Minister for External Affairs (Hon. Josiah Thomas) at that Place on 6th May, 1912; Wing Cheong Sing et al to Josiah Thomas, 7 May 1912, NAA: A1, $1912 / 10547$.

${ }^{4}$ Notes of Deputation from Chinese Residents of Darwin Which Waited Upon the Minister for External Affairs (Hon. Josiah Thomas) at that Place on 6th May, 1912, NAA: A1, 1912/10547; Atlee Hunt to Administrator of the NT, 30 May 1912, NAA: A1, 1912/6611.

5 J Kēhaulani Kauanui, '“A Structure, Not an Event": Settler Colonialism and Enduring Indigeneity.' Lateral, 5(1), 2016, <http://csalateral.org/wp/issue/5-1/forum-alt-humanities-settler-colonial ism-enduringindigeneity-kauanui/>. See also Audra Simpson, 'Whither Settler Colonialism,' Settler Colonial Studies, 6(4), 2016, p. 440.

6 Patrick Wolfe, Settler Colonialism and the Transformation of Anthropology: The Politics and Poetics of an Ethnographic Event, London: Cassell, 1999, p. 2; Patrick Wolfe, 'Introduction' in The Settler Complex: Recuperating Binarism in Colonial Studies, Patrick Wolfe (ed), Los Angeles: UCLA American Indian Studies Center, 2016, p. 9.

${ }^{7}$ Lorenzo Veracini, Settler Colonialism: A Theoretical Overview, Basingstoke: Palgrave Macmillan, 2010, pp. 53-74. See also Patrick Wolfe, 'Introduction', p. 4.

8 Crystal McKinnon, 'Expressing Indigenous Sovereignty: The Production of Embodied Texts in Social Protest and the Arts', PhD Thesis, Department of Archaeology and History, La Trobe University, 2018, p. 10. See also Joanne Barker, 'For Whom Sovereignty Matters' in Sovereignty Matters: Locations of Contestation and Possibility in Indigenous Struggles for Self-Determination, Joanne Barker (ed), Lincoln: University of Nebraska Press, 2005, p. 21; Aileen Moreton-Robinson, 'Introduction' in Sovereign Subjects: Indigenous Sovereignty Matters, Aileen Moreton-Robinson (ed), Sydney: Allen \& Unwin, 2007, p. 2; Minoru Hokari, Gurindji Journey: A Japanese Historian in the Outback, Sydney: UNSW Press, 2011, pp. 215-19, 230. ${ }^{9}$ Dean Itsuji Saranillio, 'Why Asian Settler Colonialism Matters: a thought piece on critiques, debates, and Indigenous difference,' Settler Colonial Studies, 3(3-4), 2013, pp. 286, 288.

10 On settler sovereignty as counter-sovereignty see Manu Vimalassery, "The Prose of CounterSovereignty' in Formations of United States Colonialism, Alyosha Goldstein (ed), Durham: Duke University Press, 2014, pp. 87-109.

11 Wolfe, Settler Colonialism and the Transformation of Anthropology, p. 1; Patrick Wolfe, 'Settler colonialism and the elimination of the native', Journal of Genocide Research, 8(4), 2006, pp. 387-409; Ben Silverstein, 'Patrick Wolfe (1949-2016)', History Workshop Journal, 82(1), 2016, p. 317. See Lorenzo Veracini, "'Settler Colonialism": Career of a Concept', Journal of Imperial and Commonwealth History, 41(2), 2013, pp. 313-33; Nancy Shoemaker, 'A Typology of Colonialism,' Perspectives on History, October 2015, <https://www.histori ans.org/publications-and-directo ries/perspectives-on-histo ry/october2015/a-typology-of-colonialism>; K. Tsianina Lomawaima, 'Indigenous Studies,' American Quarterly, 68(1), 2016, p. 150; Jerry Bannister, 'Settler Colonialism and the Future of Canadian History,' Acadiensis, 18 April 2016, <https://acadiensis.wordpress.com/2016/04/18/settl er-colonialism-and-the-future-ofcanadian-history/>.

12 Patrick Wolfe, 'History and Imperialism: A Century of Theory, from Marx to Postcolonialism', American Historical Review, 102(2), 1997, pp. 399, 418-19; Wolfe, Settler Colonialism and the Transformation of Anthropology, pp. 1-2, 167-8.

${ }^{13}$ Aileen Moreton-Robinson, 'Writing off Treaties: White Possession in the United States Critical Whiteness Studies Literature' in Transnational Whiteness Matters, Aileen Moreton-Robinson, Maryrose Casey, and Fiona Nicoll (eds), Plymouth: Lexington Books, 2008, pp. 83-4.

14 This work provides an ontological basis for differentiating between white settlers and those who may instead be termed foreigners. See Toula Nicolacopoulos and George Vassilacopoulos, Indigenous Sovereignty and the Being of the Occupier: Manifesto for a White Australian Philosophy of Origins, Melbourne: re.press, 2014.

15 Veracini, Settler Colonialism, 17, 30. See also Lorenzo Veracini, The Settler Colonial Present, Basingstoke: Palgrave Macmillan, 2015, pp. 44-8. Nadia Rhook has similarly described a triangular settler colonial structure, building on the spatial metaphor to describe triangles of mobility, of affect, and of subjectivity 
that inflect the form and substance of settler colonialism. Nadia Rhook, “Annamese Coolies" at Australian ports: Charting Colonial Geographies of Emotion, and Settler Memory, from French Vietnam to New Caledonia via Interwar Australia,' Australian Historical Studies, 48(3), 2017, p. 402.

${ }^{16}$ Jodi Byrd, The Transit of Empire, Minneapolis: University of Minnesota Press, 2011, pp. xix, xxxix, 53, 119. See also Shona N Jackson, Creole Indigeneity: Between Myth and Nation in the Caribbean, Minneapolis: University of Minnesota Press, 2012, p. 3; Eve Tuck and Marcia McKenzie, Place in Research: Theory, Methodology, and Methods, New York: Routledge, 2015, p. 68. For Manu Vimalassery, Juliana Hu Pegues, and Alyosha Goldstein, Byrd's invocation of the arrivant 'destabilize[s] the settler/native binary' rather than instantiating a supplementary third positionality. Manu Vimalassery, Juliana Hu Pegues, and Alyosha Goldstein, 'On Colonial Unknowing', Theory \& Event, 19(4), 2016.

${ }^{17}$ And they have, as well, often disrupted the other. See Wolfe, 'Introduction', p. 3.

${ }^{18}$ Eve Tuck and K. Wayne Yang, 'Decolonization is not a metaphor', Decolonization, 1(1), 2012, p. 7. See also Patrick Wolfe, 'Race and the Trace of History' in Studies in Settler Colonialism: Politics, Identity, Culture, Fiona Bateman and Lionel Pilkington (eds), Basingstoke: Palgrave Macmillan, 2011, p. 289; La Paperson, 'A ghetto land pedagogy: an antidote for settler environmentalism,' Environmental Education Research 20(1), 2014, p. 116.

19 On the question of 'settlers of colour', see Bonita Lawrence and Enakshi Dua, 'Decolonizing Antiracism,' Social Justice, 32(4), 2005, p. 134; Nandita Sharma and Cynthia Wright, 'Decolonizing Resistance, Challenging Colonial States,' Social Justice, 35(3), 2008-9, p. 123.

${ }^{20}$ See, for example, the Australian government publication that is intended to be read by all those seeking to become Australian citizens, which instructs readers that by 'joining the Australian community, you will inherit this history' of nation-building on Indigenous land. While the publication acknowledges that 'Australia is an ancient land' and that '[o] ur [note the crucial possessive] Indigenous cultures are the oldest continuing cultures in the world', it also reminds readers that citizenship will signal their affiliation to settler law. Indigenous sovereignty is the silent referent here, alluded to in a spirit of disavowal as new citizens are instructed in the ways they can commit to a multicultural nation. See Commonwealth of Australia, Australian Citizenship: Our Common Bond, Canberra: Department of Home Affairs, 2018, pp. 3, 9, 51.

${ }^{21}$ Patrick Wolfe, 'Recuperating Binarism: a heretical introduction', Settler Colonial Studies, 3(3-4), 2013, p. 263; Dean Itsuji Saranillio, 'Why Asian settler colonialism matters: a thought piece on critiques, debates, and Indigenous difference,' Settler Colonial Studies, 3(3-4), 2013, p. 282.

${ }^{22}$ Iyko Day, 'Being or Nothingness: Indigeneity, Antiblackness, and Settler Colonial Critique', Journal of the Critical Ethnic Studies Association, 1(2), 2015, pp. 106-7; Nadia Rhook, “'Turban-clad British Subjects:

Tracking the Circuits of Mobility, Visibility, and Sexuality in Settler Nation-Making', Transfers, 5(3), 2015, pp. 104-22; Shaista Patel, 'Complicating the Tale of "Two Indians": Mapping "South Asian" Complicity in White Settler Colonialism Along the Axis of Caste and Anti-Blackness', Theory \& Event, 19(4), 2016; Andonis Piperoglou, 'Greeks or Turks, "White or Asiatic": Historicising Castellorizian RacialConsciousness, 1916-1920', Journal of Australian Studies, 40(4), 2016, pp. 387-402.

${ }^{23}$ Byrd, Transit of Empire, p. xx; Saranillio, 'Why Asian Settler Colonialism Matters', p. 281.

${ }^{24}$ Candace Fujikane, 'Asian Settler Colonialism in the U.S. Colony of Hawai'i' in Asian Settler Colonialism: From Local Governance to the Habits of Everyday Life in Hawai'I, Candace Fujikane and Jonathan Y Okamura (eds), Honolulu: University of Hawai'i Press, 2008, p. 9.

25 Aileen Moreton-Robinson, The White Possessive: Property, Power, and Indigenous Sovereignty, Minneapolis: University of Minnesota Press, 2015, p. 11.

${ }^{26}$ Moreton-Robinson, 'Writing off Treaties', p. 84; Haunani-Kay Trask, 'Settlers of Color and "Immigrant" Hegemony: "Locals" in Hawai'i' in Asian Settler Colonialism: From Local Governance to the Habits of Everyday Life in Hawai'I, Candace Fujikane and Jonathan Y Okamura (eds), Honolulu: University of Hawai'i Press, 2008, p. 48. See also J. Kēhaulani Kauanui, 'Tracing Historical Specificity: Race and the Colonial Politics of (In)Capacity', American Quarterly, 69(2), 2017, pp. 259-63.

27 Stuart Hall, 'Pluralism, Race and Class in Caribbean Society' in Race and Class in Post-Colonial Society: A Study of Ethnic Group Relations in the English-Speaking Caribbean, Bolivia, Chile and Mexico, UNESCO (ed), Paris: Unesco, 1977, p. 162.

${ }^{28}$ Beenash Jafri, 'Desire, Settler Colonialism, and the Racialized Cowboy,' American Indian Culture and Research Journal, 37(2), 2013, p. 76.

${ }^{29}$ See, eg, Joanne Barker (ed), Sovereignty Matters: Locations of Contestation and Possibility in Indigenous Struggles for Self-Determination, Lincoln: University of Nebraska Press, 2005; Ann Laura Stoler, 'On Degrees of Imperial Sovereignty', Public Culture, 18(1), 2006, pp. 125-46; Kevin Bruyneel, The Third Space of Sovereignty: The Postcolonial Politics of U.S.-Indigenous Relations, Minneapolis, University of Minnesota Press, 2007; Aileen Moreton-Robinson (ed), Sovereign Subjects: Indigenous Sovereignty 
Matters, Sydney: Allen \& Unwin, 2007; Lauren A Benton, A Search for Sovereignty: Law and Geography in European Empires, 1400-1900, Cambridge: Cambridge University Press, 2009.

${ }^{30}$ For Dennison, studying the relationships and negotiations between the Osage nation and American county, state, and federal governments, this entanglement constitutes an inescapable web. Jean Dennison, 'Entangled sovereignties: The Osage Nation's interconnections with governmental and corporate authorities', American ethnologist 44(4), 2017, p. 685. See also Jessica Cattelino's description of 'sovereign interdependencies'. Jessica Cattelino, High Stakes: Florida Seminole gaming and sovereignty, Durham: Duke University Press, 2008, pp. 161-91.

31 Vimalassery, 'The Prose of Counter-Sovereignty', p. 88.

32 See also Mark Rifkin's study of 'the ways settler sovereignty continually is activated, circulated, and materialized within and through the "lived hegemony" of everyday experience', at least in part through the 'historical and persistent deferral of Native sovereignty'. This, then, demands an attention to the processes and practices of 'sovereignty-making'. Mark Rifkin, Settler Common Sense: Queerness and Everyday Colonialism in the American Renaissance, Minneapolis: University of Minnesota Press, 2014, pp. $11,14$.

33 Moreton-Robinson, The White Possessive, pp. 11-13; Moreton-Robinson, 'Introduction', p. 2. A similar argument, with reference to eastern Cape York, is made by Marcia Langton, 'The Edge of the Sacred, the Edge of Death: Sensual Inscriptions' in Inscribed Landscapes: Marking and Making Place, Bruno David and Meredith Wilson (eds), Honolulu: University of Hawai'i Press, 2002, p. 255.

${ }^{34}$ Alexis Wright, 'On writing Carpentaria', HEAT, 13, 2007, pp. 79-80, 84; Alexis Wright, 'A Weapon of Poetry', Overland, 193, 2008, p. 21. See also Anne Brewster, 'Indigenous Sovereignty and the Crisis of Whiteness in Alexis Wright's Carpentaria', Australian Literary Studies, 25(4), 2010, p. 88.

35 This argument on the nature of Indigenous dispossession draws on Glen Coulthard's work on ways the Dene experience the 'settler colonial relationship' in northern Canada. Glen Sean Coulthard, Red Skin, White Masks: Rejecting the Colonial Politics of Recognition, Minneapolis: University of Minnesota Press, 2014, pp. 6-7, 11, 13.

36 Baldwin Spencer, Wanderings in Wild Australia, London: Macmillan, 1928, Vol II, pp. 612-14; Samantha Wells, 'Labour, Control and Protection: The Kahlin Aboriginal Compound, 1911-38', in Settlement: A History of Australian Indigenous Housing, Peter Read (ed), Canberra: Aboriginal Studies Press, 2000, pp. 64-74.

37 Xavier Herbert quoted in Risk v Northern Territory of Australia [2006] FCA 404, [285].

38 Pauline Baban quoted in Saltwater People: Larrakia Stories from around Darwin, Samantha Wells (ed), Darwin: Larrakia Nation Aboriginal Corporation, 2001, p. 79.

${ }^{39}$ Northern Land Council on behalf of the traditional owners, Kenbi Land Claim to vacant crown land in the Cox Peninsula Bynoe Harbour and Port Patterson areas of the Northern Territory of Australia, Darwin: Northern Land Council, 1979, pp. 170-3.

${ }^{40}$ See al so Donna Odegaard Robb, 'Two Laws - One Land: Reflections of a Larrakia Woman,' Newcastle Law Review, 7(1), 2003, pp. 35-52.

41 'Daisy Ruddick' in Under the Mango Tree: Oral Histories with Indigenous People from the Top End, collected by Peg Havnen, Darwin: NT Writers' Centre, 2001, p. 45.

42 The Chinese deputies described their call for the right to employ Aboriginal workers as a call for 'the right to live'. Government reports described white settlers' reliance on Aboriginal domestic and stock workers in similar terms. George Buchanan, Northern Territory Development and Administration: Report, Melbourne: Victorian Government Printer, 1925, pp. 14-15; Report of the Board of Inquiry Appointed to Inquire into the Land and Land Industries of the Northern Territory of Australia, Cmd. Paper No. 4, 1937, p. 72.

${ }^{43}$ Littleton Groom, second reading speech, Northern Territory Acceptance Bill, Parliamentary Debates, 30 July 1909, p. 1880; Lee Batchelor, Northern Territory Acceptance Bill (No 2), Parliamentary Debates, 6 October 1910, p. 4250.

${ }^{44}$ Alfred Deakin, Parliamentary Debates, House of Representatives, 15 October 1909, pp. 4579, 4628-30; James Fenton, Northern Territory Acceptance Bill (No 2), Parliamentary Debates, 13 October 1910, p. 4542.

${ }^{45}$ Census of the Commonwealth of Australia, Melbourne: Government Printer, 1911, vol. II, p. 904; Commonweal th Bureau of Census and Statistics, Official Yearbook of the Commonwealth of Australia, Containing Authoritative Statistics for the Period 1901-1920 and Corrected Statistics for the Period 1788 to 1900, Melbourne: Government Printer, No. 14 of 1921, p. 988.

46 Wing Cheong Sing et al to Josiah Thomas, 7 May 1912, NAA: A1, 1912/10547.

${ }^{47}$ Ah Chong et al to Mr Justice Mitchell, 22 March 1911, NAA: A1, 1912/10547; Petition to the Honorable Josiah Thomas, Minister of State for External Affairs, n.d., NAA: A1, 1912/6611. 
${ }^{48}$ See Ben Silverstein, Governing Natives: Indirect Rule and Settler Colonialism in Australia's North, Manchester: Manchester University Press, 2019. 